\title{
Eimeria spp. (Apicomplexa: Eimeriidae) of marsupials (Mammalia: Didelphimorphia) in southern Bahia, Brazil
}

\author{
Eimeria spp. (Apicomplexa: Eimeriidae) de marsupiais (Mammalia: Didelphimorphia) \\ na regiáo sul da Bahia, Brasil \\ Hllytchaikra Ferraz Fehlberg'; Pedro de Alcântara Brito Junior ${ }^{1}$; Martín Roberto del Valle Alvarez²; \\ Bruno Pereira Berto ${ }^{3}$; George Rêgo Albuquerque ${ }^{1 *}$ \\ ${ }^{1}$ Departamento de Ciências Agrárias e Ambientais, Universidade Estadual de Santa Cruz - UESC, Ilhéus, BA, Brasil \\ ${ }^{2}$ Departamento de Ciências Biológicas, Universidade Estadual de Santa Cruz - UESC, Ilhéus, BA, Brasil \\ ${ }^{3}$ Departamento de Biologia Animal, Instituto de Ciências Biológicas e da Saúde, Universidade Federal Rural do Rio de Janeiro - \\ UFRRJ, Seropédica, RJ, Brasil
}

Received April 21, 2018

Accepted August 06, 2018

\begin{abstract}
The occurrence of Eimeria Schneider, 1875 in mammals of the order Didelphimorphia indicates the infection-predisposition of these animals, which in turn is mainly determined for their eating habits. The objective of this work was to evaluate the parasitism of Eimeria spp. in marsupials of the Atlantic Forest of the southern region of Bahia. Fecal samples were collected from marsupials captured in the regions of Ilhéus, Una, Belmonte and Mascote, with traps of the Sherman model $(23 \times 8 \times 9 \mathrm{~cm})$, Tomahawk $(50 \times 17 \times 17 \mathrm{~cm})$ and pitfall and analyzed by Sheather's modified centrifugal-flotation method. Oocysts were identified by microscopical evaluation of their morphology and morphometry. Didelphis aurita Wied-Neuwied, 1826, Gracilinanus agilis Burmeister, 1854, Monodelphis americana Müller, 1776, Marmosa demerarae O. Thomas, 1905 and Marmosa murina Linnaeus, 1758 were parasitized by Eimeria philanderi Lainson \& Shaw, 1989 and Eimeria gambai Carini, 1938. Mixed parasitism for these two coccidia was observed in two of the 56 marsupials sampled. In conclusion, this work registers new hosts for E. philanderi and E. gambai, as well as the state of Bahia as a new distribution site for these coccidia.
\end{abstract}

Keywords: Atlantic forest, parasitism, Eimeria philanderi, Eimeria gambai.

\section{Resumo}

A ocorrência de Eimeria Schneider, 1875 em mamíferos da ordem Didelphimorphia, indica a predisposição à infecção desses animais, que, por sua vez, é determinada principalmente por seus hábitos alimentares. O objetivo do presente trabalho foi avaliar o parasitismo por Eimeria spp. em marsupiais da Mata Atlântica da região Sul da Bahia. Amostras fecais foram coletadas de marsupiais capturados nas regiōes de Ilhéus, Una, Belmonte e Mascote, com armadilhas do modelo de Sherman $(23 \times 8 \times 9 \mathrm{~cm})$, Tomahawk $(50 \times 17 \times 17 \mathrm{~cm})$ e queda e analisado pelo método de centrífugo flutuação modificado de Sheather. Os oocistos foram identificados pela avaliação microscópica de sua morfologia e morfometria. Didelphis aurita Wied-Neuwied, 1826, Gracilinanus agilis Burmeister, 1854, Monodelphis americana Müller, 1776, Marmosa demerarae O. Thomas, 1905 e Marmosa murina Linnaeus, 1758 foram parasitados por Eimeria philanderi Lainson \& Shaw, 1989 e Eimeria gambai Carini, 1938. Parasitismo misto para esses dois coccidios foi observado em dois dos 56 marsupiais amostrados. Em conclusão, este trabalho registra novos hospedeiros para E. philanderi e E. gambai, bem como o estado da Bahia como um novo local de distribuiçáo para esses coccidios.

Palavras-chave: Mata atlântica, parasitismo, Eimeria philanderi, Eimeria gambai.

${ }^{*}$ Corresponding author: George Rego Albuquerque. Departamento de Ciências Agrárias e Ambientais, Universidade Estadual de Santa Cruz - UESC,

Rodovia Jorge Amado, Km 16, Salobrinho, CEP 45662-900, Ilhéus, BA,

Brasil.e-mail: gralbu@uesc.br 


\section{Introduction}

Eimeria Schneider, 1875 is an intracellular protozoan that infects a wide range of vertebrate hosts. Transmission occurs by ingestion of sporulated oocysts, by direct fecal/oral contact, or by ingestion of contaminated food or water (URQUHART et al., 1987; ZANETTE et al., 2008). Infection by this protozoan can be asymptomatic or cause mild to moderate disease in domestic and wild animals (ZANETTE et al., 2008).

Eimeria species have already been described in Didelphis aurita (Wied-Neuwied, 1826) (CARINI, 1936, 1938; TEIXEIRA et al., 2007), Caluromys philander Linnaeus, 1758 (CARINI, 1937), Didelphis virginiana Kerr, 1792 (JOSEPH, 1974), Philander opossum Linnaeus, 1758 and Caluromys philander Linnaeus, 1758 (LAINSON \& SHAW, 1989), Marmosops noctivagus Tschudi, 1844 and Marmosa constantiae O. Thomas, 1904 (HECKSCHER et al., 1999), Myrmecophaga tridactyla Linnaeus, 1758 (FREITAS et al., 2006) and Didelphis albiventris Lund, 1840 (ZANETTE et al., 2008), Didelphis marsupialis Linnaeus, 1758 (VALERIO-CAMPOS et al., 2015) and Gracilinanus agilis Burmeister, 1854 (STRONA et al., 2015); however, some of these species possibly have been erroneously identified, or at least they were not clearly described and differentiated. Furthermore, based on the scientific literature, there are no reports of Eimeria spp. from marsupials in the southern region of Bahia, Brazil, as well as are totally unknown their geographical distribution and host specificity. With this in mind, we designed the current study to survey coproparasites and identify Eimeria spp. from fecal samples of marsupials captured in forest areas of the Atlantic Forest of the Southern Bahia region.

\section{Material and Methods}

This study covered 14 forest areas in four municipalities in the southern region of the State of Bahia, with three areas of cocoa agroforestry (cabruca) located in the rural area of Ilhéus (areas one to three), and eleven forest areas located in the municipalities of Una, Mascote and Belmonte (areas four to 14) (Figure 1). The study region has a tropical climate and tropical forest vegetation predominates (SAMBUICHI, 2002). All areas were located between $42 \mathrm{~m}$ and $100 \mathrm{~m}$ above sea level and were georeferenced with the Global Positioning System (GPS).

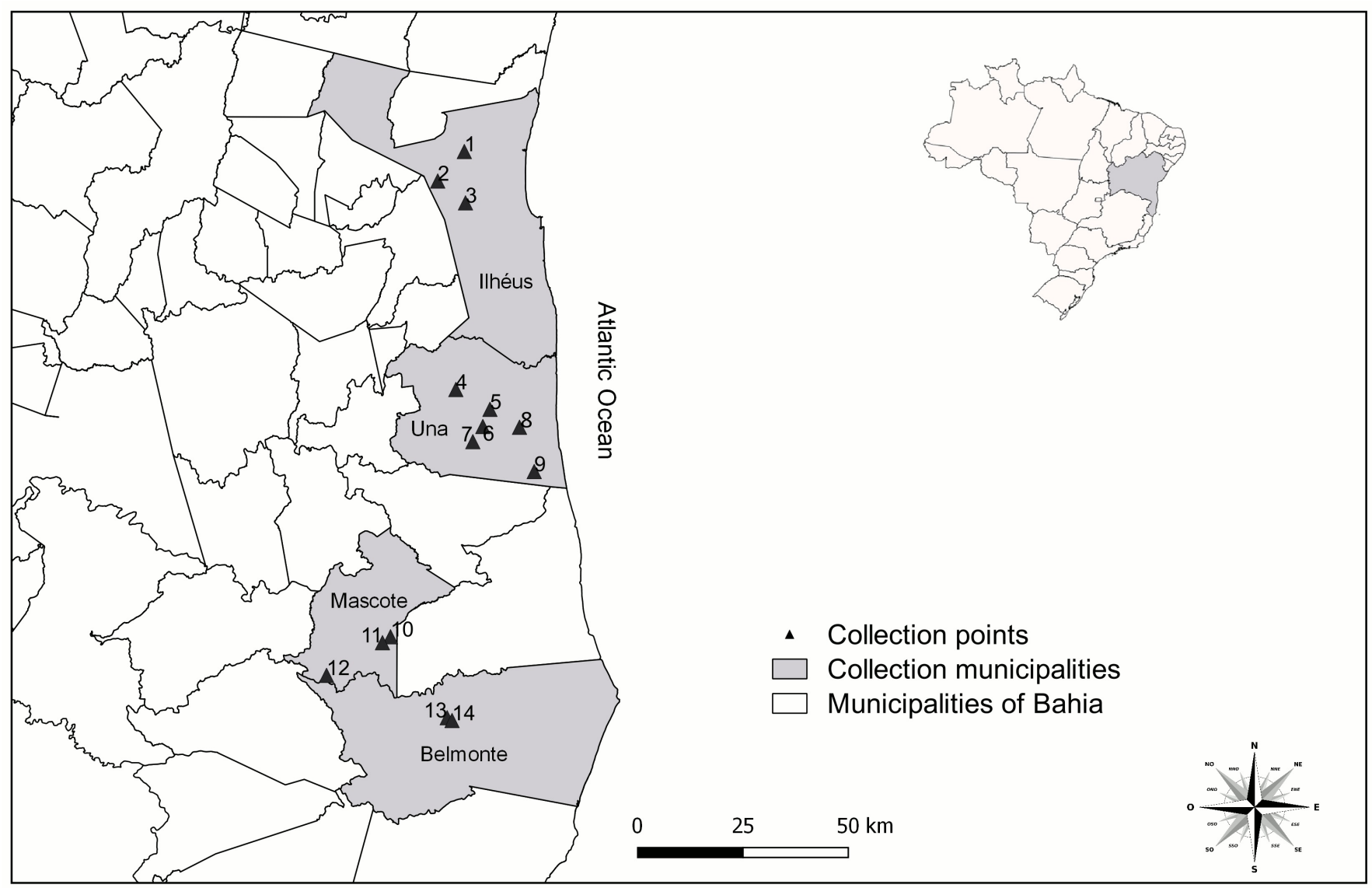

Figure 1. Map with data and areas of capture and collection of fecal samples of marsupials in southern Bahia, Brazil. Geographical coordinates

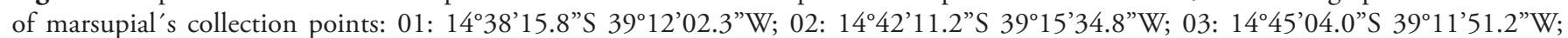

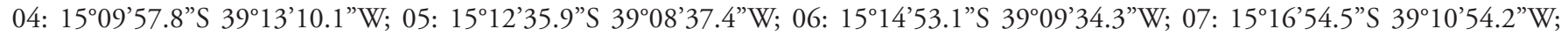

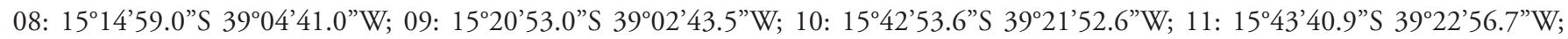

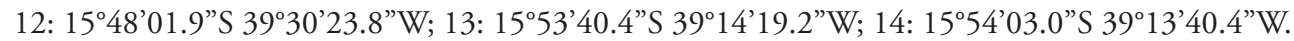


Marsupial capture was from June 2015 to December 2016 using Sherman $(23 \times 8 \times 9 \mathrm{~cm})$, Tomahawk $(50 \times 17 \times 17 \mathrm{~cm})$, and pitfall traps. Each area was divided into three plots, totaling 24 traps per plot and 72 traps per area. The study was licensed by the System of Authorization and Information on Biodiversity (SISBIO) number 17131-4 of the Brazilian Institute of Environment and Natural Renewable Resources (IBAMA) and the Council of Ethics in the Use of Animals of the State University of Santa Cruz - CEUA - UESC (No. 003/2013 and 021/2014).

After identification and collection of fecal samples, euthanasia was performed carried out through the intramuscular administration in the gluteal region of ketamine hydrochloride $(30 \mathrm{mg} / \mathrm{kg})$ associated with xylazine hydrochloride $(2 \mathrm{mg} / \mathrm{kg}$ ) according to Cubas et al. (2007). Euthanized marsupials were housed at the Universidade Estadual de Santa Cruz - Mammal Collection (CMARF-UESC). Feces with an approximate amount of 180-200 mg were collected and stored in $1.5 \mathrm{~mL}$ centrifuge tubes containing $2.5 \%$ potassium dichromate $(\mathrm{K} 2 \mathrm{Cr} 2 \mathrm{O} 7)$ in a ratio of $1: 3$ and transported to the Laboratory of Veterinary Parasitology of the Universidade Estadual de Santa Cruz (LAPVET-UESC).

The samples were processed and examined by the modified flotation technique with $1,43(\mathrm{~g} / \mathrm{L})$ density sucrose solution ( $500 \mathrm{~g}$ sucrose, $350 \mathrm{ml}$ water) by centrifugation ( $5 \mathrm{~min}$ at $2000 \mathrm{rpm}$ ) described by Sheather (1923) and modified by Duszynski \& Wilber (1997). All samples were observed under an Olympus BX51 microscope on the $20 \times$ objective and confirmed with a $40 \times$ objective. Positive samples were kept at $20-24^{\circ} \mathrm{C}$, allowing aeration for seven days to ensure complete oocyst sporulation. Sporulated oocysts were observed, photomicrographed and measured using a $100 \times$ objective microscope and immersion oil, coupled to a digital camera connected to a computer using the Image - Pro Express 6.0 program. For specific identification, morphological and morphometric guidelines described by Duszynski \& Wilber (1997) and Berto et al. (2014) were used.

\section{Results}

Fifty-six samples from Didelphis aurita, Gracilinanus agilis, Monodelphis americana, Marmosa demerarae and Marmosa murina were analyzed, and 58.92\% (33/56) were positive for Eimeria oocysts (Table 1). After sporulation and morphological and morphometric study of oocysts and sporocysts (Table 2), were identified Eimeria philanderi Lainson and Shaw, 1989 (Figure 2A, B) and/or Eimeria gambai Carini, 1938 (Figure 2C, D). Mixed parasitism was observed in $M$. murina and $M$. demerarae.

Eimeria philanderi (Figure 2A, B) was identified from D. aurita, $M$. americana, $M$. demerarae and $M$. murina, at Una, Belmonte and Mascote in Southern Bahia, Brazil (Figure 1). Their oocysts sporulated in 7-8 days and were observed as sub-spherical, with a double-layered wall (the inner one being dark and occupying about $1 / 4$ of the wall, and the outer one brown, with striations and projections occupying around 3/4 of the wall). Micropyle and oocyst residue were absent, but a polar granule was present. The sporocysts were ovoid, with prominent Stieda bodies, although the sub-Stieda was barely discernible. Parastieda bodies were absent. Sporocyst residue was present in the form of a few dispersed granules. The accompanying sporozoites had two refractile bodies. The morphometries of E. philanderi isolated from each host species are compared in Table 2.

Eimeria gambai (Figure 2C, D) was identified from G. agilis, $M$. demerarae and M. murina, at Una, Belmonte and Mascote in Southern Bahia, Brazil (Figure 1). Their oocysts sporulated in 7-8 days and were observed as ellipsoids, with a double-layered

Table 1. Distribution of Eimeria species related to marsupials and their respective collection points as indicated in Figure 1, in southern Bahia, Brazil.

\begin{tabular}{|c|c|c|c|}
\hline Hosts & Eimeria spp. & No of samples/Positive & Locality \\
\hline Didelphis aurita & Eimeria philanderi & $06 / 02$ & Area 7, Area 8 \\
\hline Monodelphis americana & Eimeria philanderi & $07 / 04$ & Area 4, Area 14 \\
\hline Gracilinanus agilis & Eimeria gambai & $05 / 04$ & Area 12 , Area 14 \\
\hline \multirow[t]{2}{*}{ Marmosa demerarae } & Eimeria philanderi & $09 / 05$ & Area 4, Area 7 , Area 8 \\
\hline & Eimeria gambai & & Area 4, Area 7, Area 8 \\
\hline \multirow[t]{2}{*}{ Marmosa murina } & Eimeria philanderi & $29 / 18$ & $\begin{array}{l}\text { Area } 4 \text {, Area } 6, \text { Area } 7, \text { Area } 8, \text { Area 9, } \\
\text { Area } 10 \text {, Area } 11 \text {, Area } 13 \text {, Area } 14\end{array}$ \\
\hline & Eimeria gambai & & Area 8, Area 10, Area 12 \\
\hline
\end{tabular}

Table 2. Morphometry of oocysts and sporocysts of Eimeria spp. identification of fecal samples of marsupials, from southern Bahia, Brazil.

\begin{tabular}{|c|c|c|c|c|c|}
\hline \multirow[b]{2}{*}{ Hosts } & \multirow[b]{2}{*}{ species } & \multicolumn{2}{|l|}{ Oocyst } & \multicolumn{2}{|l|}{ sporocyst } \\
\hline & & Size $(\mu \mathrm{m})$ & $\begin{array}{l}\text { Morphometric } \\
\text { index }(\mu \mathrm{m})\end{array}$ & Size $(\mu \mathrm{m})$ & $\begin{array}{l}\text { Morphometric } \\
\text { index }(\mu \mathrm{m})\end{array}$ \\
\hline Didelphis aurita & Eimeria philanderi & $23.40 \pm 1.42 \times 22.8 \pm 1.93$ & $1.02 \pm 0.07$ & $10.76 \pm 1.08 \times 8.65 \pm 0.51$ & $1.23 \pm 0.09$ \\
\hline Monodelphis americana & E. philanderi & $20.27 \pm 1.79 \times 19.45 \pm 1.6$ & $1.04 \pm 0.03$ & $8.74 \pm 2.06 \times 7.81 \pm 1.30$ & $1.11 \pm 0.14$ \\
\hline Gracilinanus agilis & Eimeria gambai & $25.67 \pm 3.22 \times 18.67 \pm 1.11$ & $1.37 \pm 0.16$ & $9.46 \pm 1.28 \times 8.0 \pm 0.64$ & $1.18 \pm 0.15$ \\
\hline \multirow[t]{2}{*}{ Marmosa demerarae } & E. philanderi & $22.12 \pm 1.97 \times 19.71 \pm 1.51$ & $1.02 \pm 0.11$ & $9.81 \pm 1.94 \times 7.94 \pm 0.83$ & $1.22 \pm 0.16$ \\
\hline & E. gambai & $26.30 \pm 2.48 \times 19.54 \pm 1.04$ & $1.34 \pm 0.12$ & $9.85 \pm 1.52 \times 8.27 \pm 1.12$ & $1.20 \pm 0.21$ \\
\hline \multirow[t]{2}{*}{ Marmosa murina } & E. philanderi & $23.71 \pm 2.80 \times 20.67 \pm 2.91$ & $1.15 \pm 0.11$ & $9.86 \pm 1.59 \times 8.06 \pm 1.04$ & $1.22 \pm 0.15$ \\
\hline & E. gambai & $24.11 \pm 1.81 \times 18.67 \pm 0.87$ & $1.29 \pm 0.08$ & $9.61 \pm 1.37 \times 7.48 \pm 0.53$ & $1.28 \pm 0.17$ \\
\hline
\end{tabular}




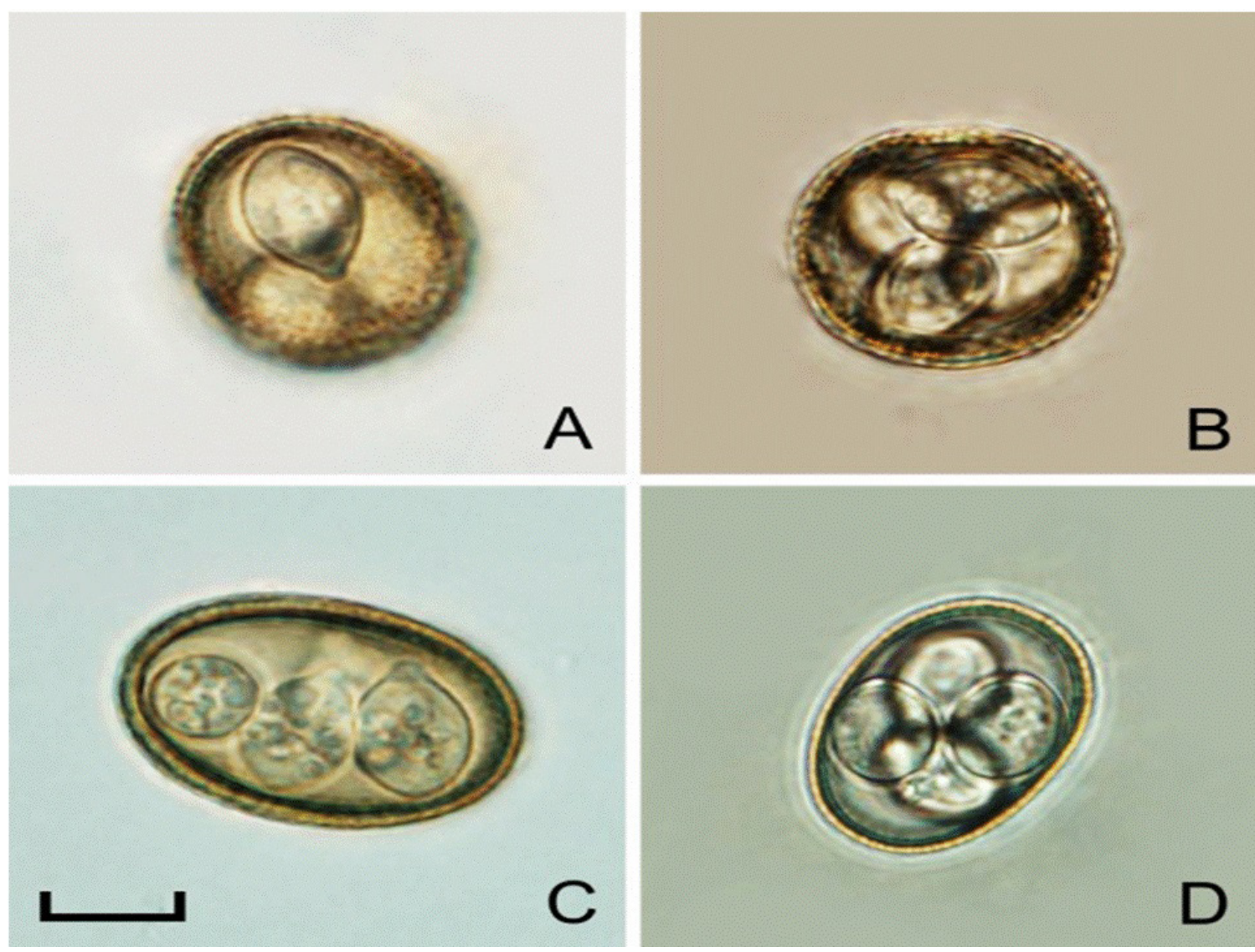

Figure 2. Photomicrographs of recovered and identified oocysts of fecal samples from marsupials in the southern region of Bahia: Eimeria philanderi in Marmosa demerarae (A) and Didelphis aurita (B); and Eimeria gambai in Gracilinanus agilis (C) and Marmosa murina (D) (scale bar = 10 $\mu \mathrm{m})$.

wall (the inner one being dark and occupying about $1 / 3$ of the wall and the outer one brown, with striations and projectoins occupying about $2 / 3$ of the wall). Micropyle, polar granule and oocyst residue were absent. The sporocysts were ovoid, with discrete Stieda bodies and sub-Stieda. Parastieda bodies were absent. Sporocyst residue was present in the form of a few dispersed granules. The accompanying sporozoites had two refractile bodies. The morphometries of E. gambai isolated from each host species are compared in Table 2.

\section{Discussion}

To the best of our knowledge, the marsupials captured in this study have not been reported previously as hosts for E. philanderi and E. gambai. This represents the first novel finding of the current report. The oocysts of both species had morphological and morphometric characteristics that were very similar to the original descriptions, and to subsequent follow-up studies (CARINI, 1938; LAINSON \& SHAW, 1989; TEIXEIRA et al., 2007).

Eimeriaphilanderi was identified in four species of marsupials in the present study. Their oocysts had morphometries (Table 2) similar to those originally described by Lainson \& Shaw (1989). The morphology also corroborates with the studies of Lainson \& Shaw (1989) and Heckscher et al. (1999), although in the present study, the presence of sub-Stieda and some differences in the intensity of roughness, striations, and wall projections were observed.

Eimeria gambai had only previously been isolated from Didelphis aurita (CARINI, 1938; TEIXEIRA et al., 2007). Our current study now extends the host range to $G$. agilis, $M$. demerarae and M. murina. The E. gambai oocysts had morphometry (Table 2) similar to that originally described by Carini (1938) and later by Teixeira et al. (2007). The presence of sub-Stieda in the sporocyst, the absence of polar granules, and differences in the intensity of roughness in the wall were observed in oocysts of this study. However, these differences were insufficient to warrant the announcement of a new species.

The delimitation of coccidian species has been discussed since the beginning of parasitology. Traditionally, the description of the new species follow the guidelines of Duszynski \& Wilber (1997), who consider that the oocysts should be compared with coccidian species that are feature-similar and belong to the same host family.

Currently with the advent of genetic sequencing techniques, the $18 \mathrm{~S}$ and $28 \mathrm{~S}$ rRNA genes and the mitochondrial cytochrome c oxidase subunit 1 ( $\operatorname{cox} 1$ ) gene have been recognized as useful loci to complementation of species characterization and in phylogenetic studies (YANG et al., 2015; SILVA-CARVALHO et al., 2018). However, this molecular tool has still limited ability to delimit species because there is no consensus on which genes are primordial and which percentage of genotypic difference separates the species 
(SILVA et al., 2016). Anyway, none of these Eimeria spp. from marsupials have ever been sequenced in these loci.

In this sense, we endorse Kunz (2002), who states that the criterion for identification of new species can not be just on the basis of a certain number of base exchanges within DNA sequence; therefore, we intend in this work to identify the coccidian species evaluating all the morphological, biological and ecological (host specificity) aspects.

It is also worth mentioning that this paper shows the inconclusive and imprecise taxonomy of marsupial coccidia, since our study prioritized the identification of the species primarily described (CARINI, 1938; LAINSON \& SHAW, 1989). This was to the detriment of more recently described species, which were not clearly differentiated from the predecessors (HECKSCHER et al., 1999; TEIXEIRA et al., 2007). In this sense, we emphasize the difficulty in delimiting Eimeria spp. from marsupials and correctly assigning them to new or already described species. Such difficulty is associated to the paucity of studies concerning Eimeria taxonomy, especially regarding some hosts, such as marsupials.

\section{Conclusion}

To the best of our knowledge, this is the first identification of Eimeria infection in marsupials captured in the State of Bahia. Although E. philanderi and E. gambai have already been described in marsupials, there are no records in the scientific literature reporting these two species parasitizing the marsupials $D$. aurita, $G$. agilis, $M$. americana, $M$. demerarae, and $M$. murina. Therefore, this paper has identified new hosts for E. philanderi and E. gambai, and indicates that the state of Bahia is a new distribution site for these coccidia.

\section{References}

Berto BP, McIntosh D, Lopes CWG. Studies on coccidian oocysts (Apicomplexa: Eucoccidiorida). Rev Bras Parasitol Vet 2014; 23(1): 1-15. http://dx.doi.org/10.1590/S1984-29612014001. PMid:24728354.

Carini A. Eimeria didelphydis n. sp. dell'intestino de Didelphis aurita. Arch Ita di Sci Med Col 1936; 17(2): 332-333.

Carini A. Sur une nouvelle Eimeria, parasite de l'intestin Du Caluromys philander. Ann Parasitol Hum Comp 1937; 15(5): 453-455. http://dx.doi. org/10.1051/parasite/1937155453.

Carini A. Mais uma Eimeria parasita do intestino do Didelphis aurita. Arq Biol 1938; 22(1): 61-62.

Cubas ZS, Silva JCR, Catão-Dias JL. Tratado de animais selvagens medicina veterinária. Vol. 1. 2a ed. São Paulo: Roca 2007.

Duszynski DW, Wilber PG. A guideline for the preparation of species descriptions in the Eimeridae. J Parasitol 1997; 83(2): 333-336. http:// dx.doi.org/10.2307/3284470. PMid:9105325.

Freitas FLC, Almeida KDS, Zanetti AS, Nascimento AA, Machado CR, Machado RZ. Espécies do gênero Eimeria (Apixomplexa: Eimeriidae) em tamanduás bandeiras (Myrmecophaga tridactyla Linnaeus, 1758) em cativeiro. Rev Bras Parasitol Vet 2006; 15(1): 29-32. PMid:16646999.
Heckscher SK, Wickesberg BA, Duszynski DW, Gardner SL. Three new species of Eimeria from Bolivian marsupials. Int J Parasitol 1999; 29(2): 275-284. http://dx.doi.org/10.1016/S0020-7519(98)00199-4. PMid:10221628.

Joseph T. Eimeria indianensis sp. n. and an Isospora sp. from the opossum Didelphis virginiana (Kerr). J Protozool 1974; 21(1): 12-15. http://dx.doi. org/10.1111/j.1550-7408.1974.tb03609.x. PMid:4817974.

Kunz W. When is a parasite species a species? Trends Parasitol 2002; 18(3): 121-124. http://dx.doi.org/10.1016/S1471-4922(01)02210-3. PMid:11854089.

Lainson R, Shaw JJ. Two new species of Eimeria and three new species of Isospora (Apicomplexa, Eimeriidae) from Brazilian mammals and birds. Bull Mus Natn Hist Nat Paris 1989; 11(2): 349-365.

Sambuichi RHR. Fitossociologia e diversidade de espécies arbóreas em cabruca (mata atlântica raleada sobre plantação de cacau) na região sul da Bahia, Brasil. Acta Bot Bras 2002; 16(1): 89-101. http://dx.doi. org/10.1590/S0102-33062002000100011.

Sheather AL. The detection of intestinal protozoa and mange parasites by a flotation technique. J Comp Pathol Ther 1923; 36: 266-275. http:// dx.doi.org/10.1016/S0368-1742(23)80052-2.

Silva LM, Rodrigues MB, Lopes BB, Berto BP, Luz HR, Ferreira I, et al. A new coccidian, Isospora parnaitatiaiensis n. sp. (Apicomplexa, Eimeriidae), from the white-shouldered fire-eye Pyriglena leucoptera (Passeriformes, Thamnophilidae) from South America. Parasitol Res 2016; 115(2): 745 749. http://dx.doi.org/10.1007/s00436-015-4798-z. PMid:26508009.

Silva-Carvalho LM, Pastura DGN, Gomes JV, Siqueira PB, Rodrigues MB, Lima VM, et al. Isospora lopesi n. sp. (Protozoa: Apicomplexa: Eimeriidae) from the eastern white-throated spadebill Platyrinchus mystaceus Vieillot (Passeriformes: Tyranni: Tyrannidae) in South America. Syst Parasitol 2018; 95(5): 455-463. http://dx.doi.org/10.1007/s11230-018-9795-z. PMid:29721660.

Strona ALS, Levenhagem M, Leiner NO. Reproductive effort and seasonality associated with male-biased parasitism in Gracilinanus agilis (Didelphimorphia: Didelphidae) infected by Eimeria spp. (Apicomplexa: Eimeriidae) in the Brazilian cerrado. Parasitology 2015; 142(8): 10861094. http://dx.doi.org/10.1017/S0031182015000402. PMid:25877479.

Teixeira M, Rauta PD, Albuquerque GR, Lopes CWG. Eimeria auritanensis n. sp. and E. gambai Carini, 1938 (Apicomplexa: Eimeriidae) from the opossum Didelphis aurita Wied-newied, 1826 (Marsupialia: Didelphidae) from southeastern Brazil. Rev Bras Parasitol Vet 2007; 16(2): 83-86. PMid:17706009.

Urquhart GM, Armaur J, Duncan JL, Dun AM, Jennings FW. Veterinary parasitology. New York: Longman; 1987.

Valerio Campos I, Chinchilla-Carmona M, Duszynski DW. Eimeria marmosopos (Coccidia: Eimeriidae) from the Opossum Didelphis marsupialis L., 1758 (Didelphimorphia: Didelphidae), in Costa Rica. Comp Parasitol 2015; 82(1): 148-150. http://dx.doi.org/10.1654/4693.1.

Yang R, Brice B, Elliot A, Ryan U. Isospora serinuse n. sp. (Apicomplexa: Eimeriidae) from a domestic canary (Serinus canaria forma domestica) (Passeriformes: Fringillidae) in Western Australia. Exp Parasitol 2015; 159: 59-66. http://dx.doi.org/10.1016/j.exppara.2015.08.020. PMid:26325434.

Zanette RA, Silva AS, Lunardi F, Santurio JM, Monteiro SG. Occurrence of gastrointestinal protozoa in Didelphis albiventris (opossum) in the central region of Rio Grande do Sul state. Parasitol Int 2008; 57(2): $217-$ 218. http://dx.doi.org/10.1016/j.parint.2007.10.001. PMid:18035587. 